\title{
HEREDITARY TRANSMISSION IN SIBERIAN SHAMANISM AND THE CONCEPT OF THE REALITY OF LEGENDS
}

\author{
Aado Lintrop
}

Belief in the hereditary transmission of shaman's gift is common to all Siberian shamanism. One can find corresponding motifs in Nganasan shamanism as well as in Tuvinian one. Often there is impossible to become a shaman without

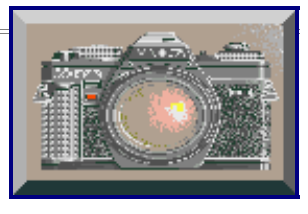
having shamans-ancestors in family. Sometimes they are namely the spirits of shamans-ancestors, who at first reveal themselves to the devotee and force him to shamanize. More frequently they are supernormal beings, who were in close relations with them - for instance former helping spirits of a shaman-ancestor. The Gilyak researcher Taksami wrote: "The boy named Koinyt, who's father - the shaman - died not long ago, fell asleep after noon and began suddenly to toss about and cry, repeating typical shouts of shamans. After waking he looked pale and tired. In dream he saw two spirits - a man and a woman, who said: "Before we played with your father, now we would play with you." (Taksami 1981, 167) Belief in the hereditary transmission of shaman's gift was firm among several peoples in Siberia. For that very reason children in famous shaman families, who desired not to become shamans, fell ill and lived as mentally or physically diseased persons. For example Nikolai Agitshev, son of the famous Ostyak-Samoyedic shaman, who worked in 1930-is together with linguist G. Prokofyev. Last years of his life Nikolai spent in loneliness, made wooden idols and fed them. (Prokofyeva 1981, 45-46)

In the present paper we attempt to explain some aspects of the belief in the hereditary transmission of shaman's talent. Associating the shaman trance with a hypnotic state, we proceed from the definition and general causes of origin of an altered state of consciousness as formulated by Arnold Ludwig (Ludwig 1968, 69) and the analysis of spirit possession given by Sheila Walker. The latter shows, elaborating on Merton Gill's and Margaret Brenman's psychoanalytical approach to hypnosis (Gill, Brenman 1961), that hypnosis and possession represent different forms of the same phenomenon - regression in the service of the ego (Walker 1972, 26-51). Together with Walker, we can say, that in many cultures the hypnotists need not to be a person. The external pressure that influences the individual and his own conscious and subconscious motives, based on different religious ideas, create a subsystem of the ego, which is the supernatural being that possesses an individual. After that, we shall come from psychoanalysis to psychology and try to explain the process of origin of the shaman's sickness, relying on the notion of the generalized realityorientation borrowed from Roland Shor. He termed so a structured frame of reference that characterizes a normal state of consciousness and supports, interprets and gives meaning to all the experience of an individual. (Shor 1959, 585) Shor stated that hypnosis is a complex of two processes, one of which is the construction of a special, temporary orientation and the other is the relative fading of the generalized reality-orientation into non-functional unawareness. (A.-L. Siikala's resumé of theses of Shor - Siikala 1978, 50) To mark the temporary orientation that enables possession (or, more narrowly, the shaman's sickness), we are using the term reality of legends. This is a system which springs from religious images transmitted by tradition and which arises onto generalized reality-orientation in some cases of altered state of consciousness. Applying it, we state that the shaman's sickness common among the Siberian peoples represents an acute manifestation of the shaman's world induced by an activation of the reality of legends and caused by any event or provocation that can be interpreted appropriately. The novice is possessed not only by one particular supernatural being but the whole world beyond with its inhabitants. Although familiar 
from legends and myths, this unexpectedly visualized world is still strange and frightening. It is split by antagonistic forces - on the one hand the regulating, systematizing and typologizing effect of a cultural tradition, on the other hand the individualizing, scattering forces of the candidate's subconscious desires, fears and impulses. During initiation these are balanced and the visions of the novice become fairly traditional. The candidate adapts himself to the reality of legends - that is becomes a shaman.

The shaman's sickness can be caused by any event that traditionally can be interpreted as a manifestation of the shaman's gift. Very important is the faith in its hereditary character, because it is this feature that disposes the novice and his relatives to look for the corresponding signs. This very feature creates the external pressure that influences the novice and that, together with his subconscious motivation, starts the reality of legends and removes the generalized reality-orientation into relatively non-functional state. By reading the stories about becoming a shaman we can indirectly decide, how strong that external pressure may be. A Kirghiz shaman Suimenbai told: "My grandfather and grandmother were shamans like my father and mother. When father died, spirits (jinn) chose my elder brother Keregebai to be their master. But Keregebai desired not to become a shaman. This cost him dear - his dead body was found behind the winter house. The second brother Sarynzits too did not want to become a shaman. Someday he rode on ambling horse and suddenly cried: "Jinn, jinn!" The horse carried him into steppe. In their way there was a well; brother tumbled off the horse and broke his neck. I was then 30 years old. Someday I went to seek for camels. It was a time of sunset. I went into bushes. Suddenly I saw, that from one side there was coming multitude of mullahs; from other side approached herd of warriors. I was frightened and lost consciousness. It was over midnight when I awoke and went home. My hands trembled and I felt giddy. At home I lied down and heard, how jinn speak: "Let's take Suimenbai to be our master."' (Alektorov 1900, 32)

The experiences of the altered state of consciousness are, for the most part, determined by the knowledge that the candidate acquired by observing the actions and listening to the stories and songs of his parent or grandparent-shaman. As the position of a shaman presupposes very good knowledge of the oral tradition, shamans usually were famous story-tellers and singers. For that very reason shaman's children and grandchildren were more familiar with the descriptions of upper or lower worlds and supernatural beings than other children. How important were descriptions of that kind, we can see from following example: A 15 years old samoyed boy was apprenticed to an old shaman. The learning started from legends. Matias Aleksanteri Castren wrote: "Imagination of the disciple was aroused with various stories about samoyedic world of spirits." Then two experienced shamans blindfolded the boy. They gave him drum and told to beat it. One of them simultaneously cuffed at the back of pupil's head, the other beaten his back. After a little it was getting light before boy's very eyes and he saw, that multitude of little shamans was dancing on his arms and legs. (Mikhaylovskiy 1892, 100)

Analyzing the motifs of the stories about becoming a shaman, one may say that some of these are expressions of the transformation of the personality of the devotee - its adaptation into the frames of tradition. Motifs of that kind are: dissection of the shaman's body; countering over, smithing and hardening his skeleton and muscles; getting the new eyes and boring through the ears; bringing the reborn shaman up in the iron or stone cradle et cetera. Other motifs show how the experiences of the initiation period are subordinated to traditionary control. Such motifs are: learning from supernatural beings; seeking for allies among spirits; getting helping spirits et cetera. According to autobiographies told by the Nganasan shamans, we may admit that the spirit whom candidate meets for the first time during a dream journey of his initiation period should first be recognized. The recognition, naming or guessing of a supernatural being is one of the examples of traditionary 
control. Also, the devotee has to recognize and name the places visited by him, and objects of importance that he meets. Recognition of a vision equals to framing it into traditional form. The would-be shaman either unriddles the visions of his initiation period and, in this way, gives them a sufficiently traditional form, or eliminates them. About the recognition of the visions we can know more through the medium of the shamans' autobiographies. Semen Momde, a Nganasan shaman, told: "We saw the tent all covered with ice. A man and a woman were sitting there; a naked boy was walking around in the tent. Tent covers were made from snow and ice; fire in the middle of the tent was hardly burning. "Who are you, from what places are you coming?" they asked. I answered: "Two are leading me. They told me to go along the ancient path. Probably you are spirits of sicknesses." There were all kinds of pots and cauldrons in the tent; all filled with pus. They told me to guess - the boy asked: "Who am I?" I answered: "Probably you are headache." Old man and woman asked: "Guess, who are we?" - "The old man is the beginning of tuberculosis. The old woman is the beginning of cough." They said: "You are right. If such a sickness would come to your people, you would call for us and we help you."" (Popov 1984, 102)

However, it is not enough to merely recognize the places and beings of supernatural world. To gain full control over the vision, it must be described in words - to sing or retell it. For singing or retelling one's experiences means giving a more traditional form to an individual experience. Individuals who are acquainted since early childhood with shamanic tradition have naturally more necessary knowledge for expressing in words their visions than other people. It is during the initiation period that the devotee acquires most of his songs - descriptions of helping spirits and journeys. A son often applies the melodies of his father's or grandfather's shaman songs.

An active traditionary control over shaman visions continues after the initiation period is over. In case of an experienced shaman, this is expressed by guessing or so-called 'quest for the right path' taking place during rituals. With the help of such guessing untypical or inappropriate elements are eliminated from the shaman actions. Advice sought by the shamans from people who have a good knowledge of the tradition in a difficult situation is also a part of the traditionary control. Often, an experienced shaman has to continue recognizing and naming objects and beings of the supernatural world during the rites. For example, Tubyaku Kosterkin, a Nganasan shaman, had three helping spirits called hoshitele. They helped him to recognize several places of the upper world and lower world as well as objects met on shaman journeys that 'did not appear to him as they actually were'. (Gratcheva 1984, 91)

\section{References}

Alektorov, A. E. Baksa (iz kirgizskikh sueveri). Izvestya Obschestva arkheologi, istori i etnografi pri Kazanskom universitete. T. XVI, vyp. 1. Kazan.

Gill, Merton M., Brenman, M. 1961. Hypnosis and Related States. Psychoanalytic Studies in Regression. New York.

Gracheva; G. K etnokulturnym svyazam nganasan. Klassifikacya shamanov. Etnokulturnye kontakty narodov Sibiri. Leningrad.

Ludwig, A. M. 1968. Altered States of Consciousness. Trance and Possession States (ed. R. Prince). Montreal.

Mikhaylovski V. 1892. Shamanstvo. Sravnitel'no-etnograficheskye ocherki. Vyp. 1. Izvestya Obschestva lubitelei estestvoznanya, antropologi i etnografi, t. LXXV. Moscow. 
Popov, A. 1984. Nganasany. Socialnoe ustroistvo i verovania. Leningrad.

Prokofyeva, E. 1981. Materialy po shamanstvu selkupov. Problemy istori obseschestvennovogo soznanya aborigenov Sibiri. Leningrad.

Shor, R. E. 1959. Hypnosis and the Concept of the Generalized Reality-Orientation. American Journal of Psychotherapy 1959 No.13. Lancaster.

Siikala, A. L. 1978. The Rite Technique of the Siberian Shaman. FF Communications 220. Helsinki.

Taksami, Ch. 1981. Shamanstvo u nihvov. Problemy istori obschestvennogo soznania aborigenov Sibiri. Leningrad.

Walker, S. 1972. Ceremonial Spirit Possession in Africa and Afro-America. Forms, Meanings and Functional Significance for Individuals and Social Groups. Leiden. 